高分子文集 (Kobunshi Ronbunshu), Vol. 35, No. 11, pp. 713-719 (Nov., 1978)

含リンビスアミド無水物と芳香族ジアミンからのポリアミドーイミドの合成*

清田 優 ${ }^{* 1} \cdot$ 佐藤 守之*1 ・槙山 正明*1

(受付 1978 年 4 月 18 日・蓄查絡了 1978 作 6 月 17 日)

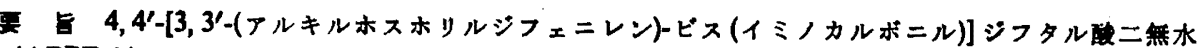

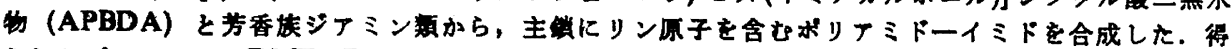
られたポリマーは, DMF, DMA, DMSO なとの有機浴婪に不浴で, 用いたジテミンが S,Pなど

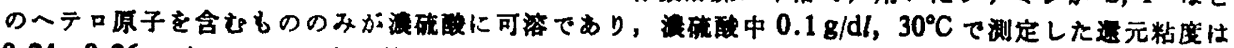

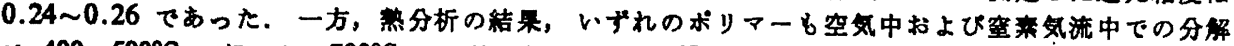

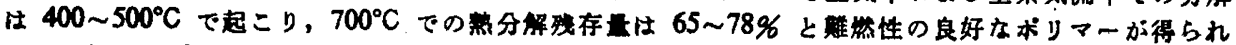

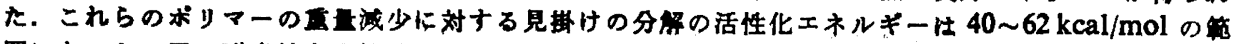
囲にあった．又，耐炎性を定性的に羽へた桔果，いずれの含リンボリアミトーイミドも焱を取り除く と、ただちに消火する程度の自己消炎性を示した。
\end{abstract}

\section{1 藉}

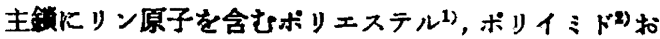
よびポリフミドタ) についての研究は数多くみられるが, 主鈛にリン原子を含むボリアミドーイミドの合成および 熱安定性に関する研究は，まだ，報告がみられない，そ こて, 著者らは含りンボリマーの合成に関する研究の一 理として, 今回は, ビス(3-フミノフェニル)フルキルホ スフィンオキシドと4(クロロホルミル)フタル酸無水物 (CFPA) からビスフミド無水物, すなわち， 4, 4'-[3, 3'(フルキルホスホリルジフェニレン)ービス(イミノカルボ ニル)]ジフタル酸二無水物 (APBDA) を合成し，これ らと芳香族ジアミンとの高温無溶媒重樎合によって，主 銷にリン原子を含むボリフミドーイミドを合成した。 又, 合成ポリマーの耐熟生，涌炎性扰よびその他の性算 について娭討を加えた. さらに, 3,3'-ジフミノジフェニ ルケトン (DDK) と CFPA が 4, 4'-[3, 3'-(シフ ルカルボニルトビス(イミノカルボニル)]シフタル酸二無 水物 (DCDA) を合成し，リン原子を炭菜原子に圈き換 えた類似棬造のボリマーを合成して，耐熱性など諸欋の 性質の比校険討を行った. (Scheme 1)

*本報を「含リンボリマーに閉ナる研究第 14 報」と する。

*1 工学院大学工莱化学科（-160 東京都新宿区西新宿 1-24-2)
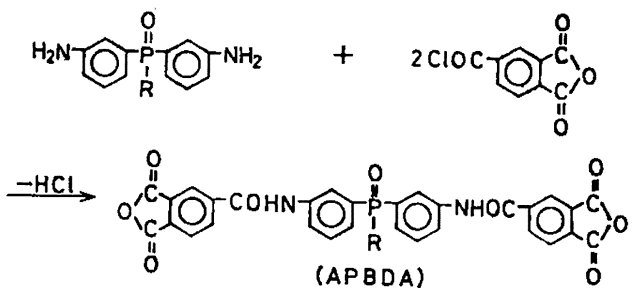

$A P B D A+\mathrm{H}_{2} \mathrm{~N}-\mathrm{R}^{\prime}-\mathrm{NH}_{2}$

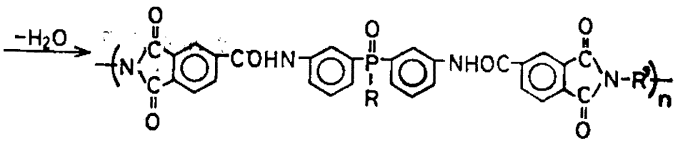

$R: \mathrm{CH}_{3}, \mathrm{C}_{4} \mathrm{H}_{9}$
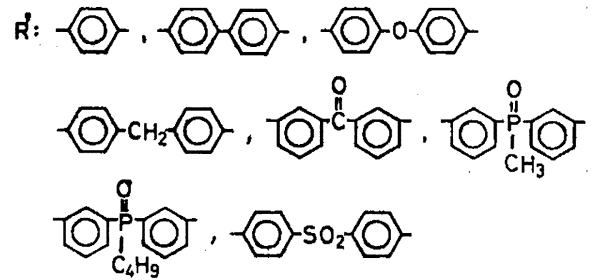

Scheme 1

2 实

\section{1 諴等}

为香族ジフミンは市服品をエタノールで再結晶して使 用した。 
$p$-フェニレンジフミン(p-PDA), $\mathrm{mp} 138.0 \sim 139.0^{\circ} \mathrm{C}$ ベンジシン (BZD), $\mathrm{mp} 115.0 \sim 116.0^{\circ} \mathrm{C}$

4,4'-ジフミノジフェニルエーテル(DDE), mp 185.0〜 $186.0^{\circ} \mathrm{C}$

4,4'-シシフミノジフェニルメタン (DDM), mp 91.0 $92.0^{\circ} \mathrm{C}$

4,4'-ジアミノジフェニルスルホン(DDS), mp 175.0 $176.0^{\circ} \mathrm{C}$

\section{2 分析}

IR スペクトルは，日本分光工莱(株) 制 IR-S 型赤外 分光光度計を用い， $\mathrm{KBr}$ 鏔郕法により測定した. NMR スペクトルは，DMSO-d d 容某として，室温で日本䉓 子(株) 制 JNM-MH-60 型を用いて $60 \mathrm{MHz}$ で测定し た.

熱分析は，(株)島津製作所整 DT-20 型により年温速 度 $10^{\circ} \mathrm{C} / \mathrm{min}$ で行った。

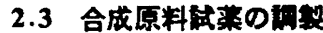

2.3.1 ヒス(3-アミノフェニル)メチルホスフィンオキ シト (BAMP)

ビス(3-ニトロフェニル)メチルホスフィンオキシドタ) $30.6 \mathrm{~g}(0.1 \mathrm{~mol})$ をエタノール $300 \mathrm{ml}$ と港塩酸 $200 \mathrm{ml}$ の混合溶液に溶解させ，塩化第一スス $180.6 \mathrm{~g}(0.8 \mathrm{~mol})$ を溶解させたェタノール溶液 $200 \mathrm{~m} l$ を少量ずつ加えて

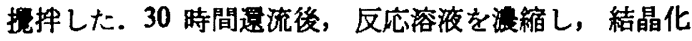
させた．生成した塩を $25 \%$ 水酸化ナトリゥム溶液 $1.5 l$ 中に港汼しながら少量ずつ加えて分解した後，目的物を クロロホルム $500 \mathrm{ml}$ を用いて数回抽出した．抽出溶液 を乾固させ，目的物をジクロロエタンで再結晶して黄白 色粉状晶 $14.6 \mathrm{~g}$ (収率 $60.0 \%$ ) を得た。 mp 145.0 $146.5^{\circ} \mathrm{C}$ (文献値 ${ }^{3)} \mathrm{mp} 145 \sim 147^{\circ} \mathrm{C}$ )

\subsection{2 ピス(3-アミノフェニル)フチルホスフィンオ キシト (BABP)}

2.3.1 と同棣にして合成した. シクロロエタンで再結 晶して黄白色粉状晶 $23.6 \mathrm{~g}$ (収率 $82.0 \%$ ）を得た。 $\mathrm{mp}$ $139.0 \sim 141.0^{\circ} \mathrm{C}$ (文献値) $\mathrm{mp} 140^{\circ} \mathrm{C}$ )

\subsubsection{3, 3'-ジアミノジフェニルケトン (DDK)}

Klemm らの方法に従って合成した. 黄白色針状結晶, $\mathrm{mp} 148.0 \sim 150.0^{\circ} \mathrm{C}$ (文献值) $\mathrm{mp} 148 \sim 149^{\circ} \mathrm{C}$ )

2.3.4 4(クロロホルミル)フタル 酸無水物 (CFPA)

Winslow らの方法に従って合成した. 白色針状結晶, mp $68.0 \sim 70.0^{\circ} \mathrm{C}$ (文献值) $\mathrm{mp} 68 \sim 70^{\circ} \mathrm{C}$ )

2.3.5 4, 4'-[3, 3'-(メチルホスホリルジフェニレン)ヒス(イミノカルポニル)]ジフタル酸二無水物 (MPBDA)

CFPA $3.40 \mathrm{~g}(16 \mathrm{mmol})$ をアセトン $100 \mathrm{ml}$ に溶解 し,トリエチルアミン $2.22 \mathrm{ml}(16 \mathrm{mmol})$ を加えた後, BAMP $1.95 \mathrm{~g}(8 \mathrm{mmol})$ を加え, 室温で 10 分间提汼 した. 反応後, トリエチルアミン塩酸塩を沪別し，再び

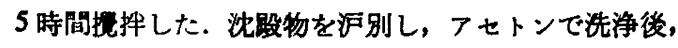
減压䇉煤した。 黄白色粉状晶 $2.12 \mathrm{~g}$ (収率 $45.0 \%$ ) を 得た. $\mathrm{mp} 315^{\circ} \mathrm{C}<$ (分解)

NMR (DMSO-d $\left.\mathrm{d}_{0}\right) \delta=10.3(\mathrm{w}, 2 \mathrm{H},-\mathrm{NH}-$ ), $7.2 \sim 8.4(\mathrm{~m}, 14 \mathrm{H}$, ペンゼン核), $1.9 \mathrm{ppm}(\mathrm{s}, 3 \mathrm{H}$, $\mathrm{CH}_{8}$ )

IR 1650 (-NHOC-), 1850, 1250 (-OCOCO-), $1430(\mathrm{P}-\mathrm{Ph}), 1170 \mathrm{~cm}^{-1}(\mathrm{P}=\mathrm{O})$

分析値

Found: C, 62.93; H, 3.77; N, 4.68; P, 5.20\%. Calcd. for $\mathrm{C}_{31} \mathrm{H}_{10} \mathrm{O}_{0} \mathrm{~N}_{2} \mathrm{P}: C, 62.63 ; \mathrm{H}, 3.20 ; \mathrm{N}$, $4.71 ; P, 5.22 \%$.

2.3.6 4, 4’-[3,3'-(7チルホスホリルジフェニレン)-ヒ ス(イミノカルボニル)]ジフタル酰二慜水物 (BPBDA)

CFPA $2.11 \mathrm{~g}(10 \mathrm{mmol})$ をアセトン $250 \mathrm{~m} /$ に溶解 し, BABP $1.44 \mathrm{~g}(5 \mathrm{mmol})$ をてセトン $50 \mathrm{ml}$ に溶解 して両液を混合し，室温で 10 分間提捧した. 反応後， 反応溶液を乾固し， $200^{\circ} \mathrm{C}$ で 1 時間加熱した：黄白色粉 状晶 $2.03 \mathrm{~g}$ (收率 $64.0 \%$ ) を得た. $\mathrm{mp} 335^{\circ} \mathrm{C}<$ (分解)

NMR (DMSO-d $\left.\mathrm{d}_{6}\right) \delta=10.5(\mathrm{w}, 2 \mathrm{H},-\mathrm{NH}-$ ), 6.6 $8.4(\mathrm{~m}, 14 \mathrm{H}$, ベンゼン核), $0.6 \sim 2.2 \mathrm{ppm}(\mathrm{s}, 9 \mathrm{H}$, $\left.\mathrm{C}_{4} \mathrm{H}_{9}\right)$

IR 1650 (-NHOC - ), 1850, 1250 (-OCOCO-), $1430(\mathrm{P}-\mathrm{Ph}), 1170 \mathrm{~cm}^{-1}(\mathrm{P}=\mathrm{O})$

分析値

Found: C, 63.24; H, 3.97; N, 4.42; P, 4.60\%.

Calcd. for $\mathrm{C}_{34} \mathrm{H}_{20} \mathrm{O}_{8} \mathrm{~N}_{2} \mathrm{P}: \mathrm{C}, 64.10 ; \mathrm{H}, 3.97 ; \mathrm{N}$, 4.40; $\mathrm{P}, 4.87 \%$.

2.3.7 4, 4' -[3, 3'-(ジフェニルカルポニル)-ヒス (1ミ ノカルボニル)]ジフタル酸二無水物 (DCDA)

CFPA $0.42 \mathrm{~g}$ (2 mmol) $30 \mathrm{ml}$ のフセトンに溶か

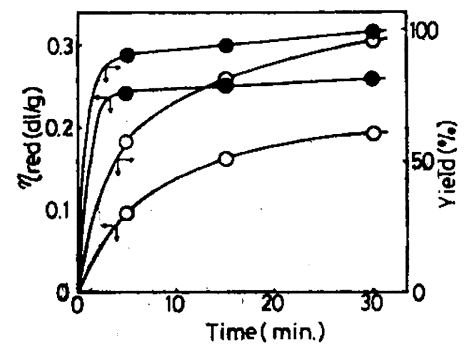

Fig. 1. Effect of reaction time and temperature on reduced viscosity of phosphorus-containing polymer obtained from DDS and BPBDA; Molar ratio, DDS/BPBDA $=1.0$.

$\eta_{\text {roa }}$ was measured at a concentration of 0.1 $\mathrm{g} / \mathrm{dl}$ in conc. $\mathrm{H}_{2} \mathrm{SO}_{4}$ at $30^{\circ} \mathrm{C}$.

$-0-: 300^{\circ} \mathrm{C},-\mathrm{O}-: 250^{\circ} \mathrm{C}$. 
含リンビスナミド無水物と若香族ジフミンからのボリナミドーイミドの合成

Table 1. Preparation of polyamide-imides.

\begin{tabular}{|c|c|c|c|c|c|}
\hline \multirow{2}{*}{$\begin{array}{c}\text { Polymer } \\
\text { No. }\end{array}$} & \multicolumn{2}{|c|}{ Monomer } & \multicolumn{3}{|c|}{ Polymer } \\
\hline & BAA*) & Diamine & $\begin{array}{c}\text { Yield } \\
(\%)\end{array}$ & Color & $\begin{array}{l}\eta_{\mathrm{rge}}^{\mathrm{b})} \\
(\mathrm{d} d / \mathrm{g})\end{array}$ \\
\hline 1 & BPBDA & $p$-PDA & 87 & Brown & - \\
\hline 2 & BPBDA & BZD & 83 & Brown & - \\
\hline 3 & BPBDA & DDE & 88 & Light brown & -- \\
\hline 4 & BPBDA & DDM & 86 & Light brown & - \\
\hline 5 & BPBDA & DDK & 81 & Yellow & - \\
\hline 6 & BPBDA & DDS & 98 & Yellow & 0.26 \\
\hline 7 & BPBDA & BAMP & 95 & Yellow & 0.24 \\
\hline 8 & BPBDA & BABP & 92 & Yellow & 0.24 \\
\hline 9 & MPBDA & $p \leadsto$ PDA & 85 & Yellow & - \\
\hline 10 & MPBDA & DDE & 81 & Brown & - \\
\hline 11 & MPBDA & DDM & 82 & Light brown & - \\
\hline 12 & MPBDA & DDS & 84 & Yellow & 0.24 \\
\hline 13 & DCDA & $p$-PDA & 90 & Brown & - \\
\hline 14 & DCDA & DDE & 82 & Brown & - \\
\hline 15 & DCDA & DDM & 88 & Black & - \\
\hline 16 & DCDA & DDS & 86 & Brown & - \\
\hline
\end{tabular}

a) BAA, Bisamide-anhydride. b) Measured at a concentration of $0.1 \mathrm{~g} / \mathrm{d} l$ in conc. $\mathrm{H}_{2} \mathrm{SO}_{4}$ at $30^{\circ} \mathrm{C}$.

し, DDK $0.21 \mathrm{~g}(1 \mathrm{mmol})$ を $20 \mathrm{ml}$ のフセトンに溶 かして両溶液を混合し，室温で 10 分間措拌した。これ を1 昼夜放㯰後, 生成物を沪別し，アセトンで数回洗浄 後, 隇王鞍嬠した。黄白色粉状晶 $0.17 \mathrm{~g}$ (収率 $30.0 \%$ ) を得た. $\mathrm{mp} 247^{\circ} \mathrm{C}<$ (分解)

NMR (DMSO- $\left.\mathrm{d}_{0}\right) \delta=10.5(\mathrm{w}, 2 \mathrm{H},-\mathrm{NH}-)$, 7.1 8.4 ppm (m, 14H, ベンゼン核)

IR $1650(-\mathrm{NHOC}-), 1850,1250$ (-OCOCO-), $1630 \mathrm{~cm}^{-1}(\mathrm{C}=0)$

\section{分析値}

Found: C, 66.53; H, 2.92; N, 5.20\%.

Calcd. for $\mathrm{C}_{51} \mathrm{H}_{10} \mathrm{O}_{8} \mathrm{~N}_{2}: C, 66.43 ; \mathrm{H}, 2.86 ; \mathrm{N}$, $5.00 \%$.

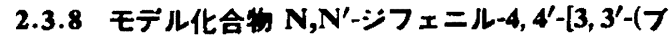
チルホスホリルジフェニレン)-ビス(イミノカル ボニル)ジフタルイミト

BPBDA $0.51 \mathrm{~g}(0.8 \mathrm{mmol})$ を DMF $20 \mathrm{ml}$ に溶解 した後， アニリン $1.43 \mathrm{ml}(16 \mathrm{mmol})$ を加え， 5 時間 這流した。 反応後, DMF を減氏留去し, ベンぜンより 再結晶して黄白色粉状晶 $0.23 \mathrm{~g}$ （収率 $38.0 \%$ ）を得た。 $\mathrm{mp} 350^{\circ} \mathrm{C}<$ (分解)

NMR (DMSO-d $\left.\mathrm{d}_{6}\right) \quad \delta=12.2(\mathrm{w}, 2 \mathrm{H},-\mathrm{NH}-$ ), $8.0 \sim 9.8(\mathrm{~m}, 24 \mathrm{H}$, ベンゼン核), $0.8 \sim 2.1 \mathrm{ppm}$ (s, $\left.9 \mathrm{H}, \mathrm{C}_{4} \mathrm{H}_{0}\right)$

IR 1780, 1710 (-OCNCO-), 1650 (-NHOC-), $1430(\mathrm{P}-\mathrm{Ph}), 1170 \mathrm{~cm}^{-1}(\mathrm{P}=0)$
分析値

Found: C, 68.71; H, 4.61; N, 7.21; P, 3.66\%. Calcd. for $\mathrm{C}_{48} \mathrm{H}_{88} \mathrm{O}_{7} \mathrm{~N}_{4} \mathrm{P}: \mathrm{C}, 70.21 ; \mathrm{H}, 4.49 ; \mathrm{N}$, 7.21; P, 3.94\%.

$$
B P B D A+2 \mathrm{H}_{2} \mathrm{~N}-\mathrm{O}
$$

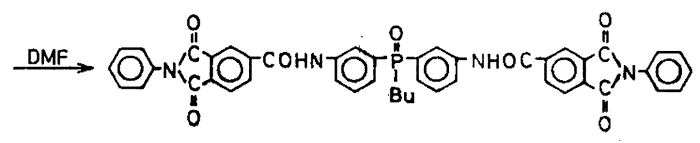

Scheme 2

\section{4 亘稬合反底}

等モルの MPBDA（または BPBDA，DCDA）およ び芳香族ジアミンをよく混合粉碎して四ッロフラスコに

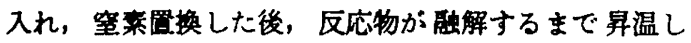
た. 融解後, $20 \mathrm{mmHg}$ の減圧下で所定温度で所定時間 反応させた，反応釉了後，反応混合物にアセトン $100 \mathrm{ml}$ を加え， 30 分間慩流して未変化物を溶解させた後，汇 別し，フセトンで十分洗浄し，減圧㛺燥した。

\section{3 结果およひ考㤹}

\section{1 モノマーおよびテデル化合物の合成}

CFPA と BAMP, BABP, DDK から，フセトン中, 室 温において脱塩化水素反応により，それぞれ MPBDA, BPBDA，DCDA を合成し，いずれの場合も黄白色粉 状晶の生成物を得た. 生成物は，実験の項に述べたよう 
Table 2. Elemental analyses of polyamide-imides.

\begin{tabular}{|c|c|c|c|c|c|c|c|c|c|}
\hline \multirow{2}{*}{$\begin{array}{c}\text { Polymer } \\
\text { No. }\end{array}$} & \multirow{2}{*}{ Brutto formula } & \multicolumn{2}{|c|}{$C(\%)$} & \multicolumn{2}{|c|}{$H(\%)$} & \multicolumn{2}{|c|}{$\mathbf{N}(\%)$} & \multicolumn{2}{|c|}{$\mathrm{P}(\%)$} \\
\hline & & Calod. & Found & Calcd. & Found & Calcd. & Found & Caled. & Found \\
\hline 1 & $\mathrm{C}_{40} \mathrm{H}_{28} \mathrm{O}_{7} \mathrm{~N} \mathbf{6}_{6} \mathrm{P} \cdot \mathrm{H}_{2} \mathrm{O}$ & 66.11 & 66.28 & 4.30 & 4.09 & 7.71 & 7.72 & 4.26 & 4.14 \\
\hline 2 & $\mathrm{C}_{66} \mathrm{H}_{38} \mathrm{O}_{7} \mathrm{~N}, \mathrm{P} \cdot \mathrm{H}_{2} \mathrm{O}$ & 68.82 & 68.17 & 4.40 & 4.32 & 6.98 & 7.00 & 3.86 & 3.64 \\
\hline 3 & $\mathrm{C}_{66} \mathrm{H}_{88} \mathrm{O}_{8} \mathrm{~N} / \mathrm{P} \cdot \mathrm{H}_{2} \mathrm{O}$ & 67.48 & 67.68 & 4.31 & 4.56 & 6.84 & 6.88 & 3.78 & 3.58 \\
\hline 4 & $\mathrm{C}_{47} \mathrm{H}_{88} \mathrm{O}_{7} \mathrm{~N} 4 \mathrm{P} \cdot \mathrm{H}_{2} \mathrm{O}$ & 68.11 & 66.94 & 4.57 & 4.60 & 6.86 & 6.71 & 3.79 & 3.58 \\
\hline 5 & $\mathrm{C}_{47} \mathrm{H}_{88} \mathrm{O}_{8} \mathrm{~N}_{4} \mathrm{P} \cdot 1.5 \mathrm{H}_{2} \mathrm{O}$ & 67.22 & 68.24 & 4.32 & 4.39 & 6.67 & 5.82 & 3.69 & 3.60 \\
\hline 6 & $\mathrm{C}_{40} \mathrm{H}_{88} \mathrm{O}_{0} \mathrm{~N}_{4} \mathrm{PS} \cdot \mathrm{H}_{2} \mathrm{O}$ & 63.74 & 64.08 & 4.07 & 4.14 & 6.46 & 5.29 & 3.57 & 2.85 \\
\hline 7 & $\mathrm{C}_{47} \mathrm{H}_{80} \mathrm{O}_{8} \mathrm{~N}_{4} \mathrm{P}_{2} \cdot \mathrm{H}_{2} \mathrm{O}$ & 63.95 & 57.22 & 4.57 & 4.74 & 6.35 & 5.69 & 7.02 & 7.10 \\
\hline 8 & $\mathrm{C}_{80} \mathrm{H}_{42} \mathrm{O}_{8} \mathrm{~N}_{4} \mathrm{P}_{2} \cdot \mathrm{H}_{2} \mathrm{O}$ & 66.22 & 57.93 & 4.89 & 4.53 & 6.18 & 5.78 & 6.83 & 6.85 \\
\hline 9 & $\mathrm{C}_{87} \mathrm{H}_{28} \mathrm{O}_{7} \mathrm{~N}_{4} \mathrm{P} \cdot 0.5 \mathrm{H}_{2} \mathrm{O}$ & 65.78 & 67.11 & 3.58 & 4.04 & 8.29 & 7.10 & 4.59 & 4.63 \\
\hline 10 & $\mathrm{C}_{48} \mathrm{H}_{28} \mathrm{O}_{8} \mathrm{~N}_{4} \mathrm{P} \cdot 0.5 \mathrm{H}_{2} \mathrm{O}$ & 67.28 & 68.42 & 3.68 & 4.30 & 7.30 & 6.24 & 4.03 & 4.40 \\
\hline 11 & $\mathrm{C}_{44} \mathrm{H}_{20} \mathrm{O}_{7} \mathrm{~N}_{4} \mathrm{P} \cdot 0.5 \mathrm{H}_{8} \mathrm{O}$ & 69.02 & 69.25 & 3.96 & 4.73 & 7.32 & 6.86 & 4.05 & 4.35 \\
\hline 12 & $\mathrm{C}_{48} \mathrm{H}_{27} \mathrm{O}_{6} \mathrm{~N}_{4} \mathrm{PS} \cdot \mathrm{O} \cdot 0.5 \mathrm{H}_{2} \mathrm{O}$ & 63.31 & 64.23 & 3.46 & 4.53 & 6.87 & 6.71 & 3.80 & 3.66 \\
\hline 13 & $\mathrm{C}_{87} \mathrm{H}_{20} \mathrm{O}, \mathrm{N}_{6} \cdot 2 \mathrm{H}_{2} \mathrm{O}$ & 66.47 & 67.90 & 3.62 & 3.88 & 8.38 & 7.22 & - & - \\
\hline 14 & $\mathrm{C}_{43} \mathrm{H}_{24} \mathrm{O}_{8} \mathrm{~N}_{4} \cdot 0.5 \mathrm{H}_{2} \mathrm{O}$ & 70.78 & 72.11 & 3.45 & 4.47 & 7.68 & 6.69 & - & - \\
\hline 15 & $\mathrm{C}_{44} \mathrm{H}_{20} \mathrm{O}_{7} \mathrm{~N}_{4} \cdot 1.5 \mathrm{H}_{2} \mathrm{O}$ & 70.49 & 70.70 & 3.90 & 3.96 & 7.47 & 6.28 & - & - \\
\hline 16 & $\mathrm{C}_{48} \mathrm{H}_{24} \mathrm{O}_{8} \mathrm{~N} / \mathrm{S} \cdot \mathrm{H}_{2} \mathrm{O}$ & 65.65 & 65.18 & 3.33 & 3.64 & 7.12 & 6.22 & - & - \\
\hline
\end{tabular}

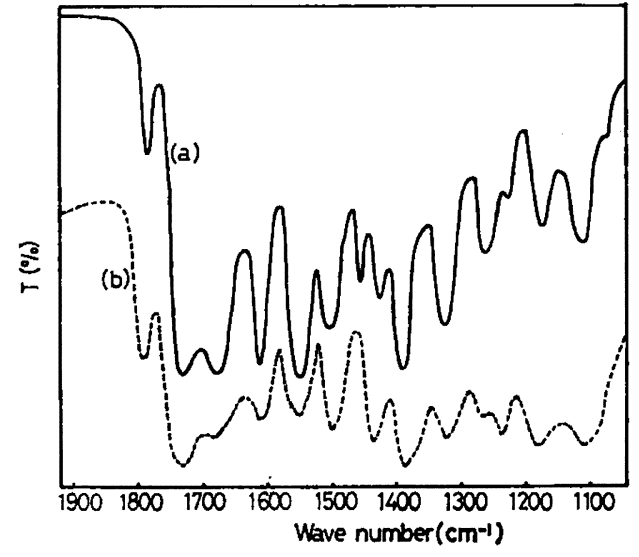

Fig. 2. IR spectra of model compound and polymer: (a) Model compound; (b) Polymer (Polymer No. 1).

に，NMR スペクトル，IR スペクトル，および元秦分 析から目的物であることを確認した。

又, BPBDA とアニリンから，DMF 中罱流下でモデ 儿化合物を合成し，モノマーと同様にして確認した。

\section{2 含リンポリアミトーーイミトの合成}

一般に，ポリイミドの合成法としては，二酸無水物と ジフミンを低温溶液重樎合によってポリアミック酸と し，次いでこれを加熱処理してイミド化する方式がとら れている7゙．著者らもこの方式に従って，ます溶液法を 試みた。すなわち，BPBDA と p-PDA から，溶媒と

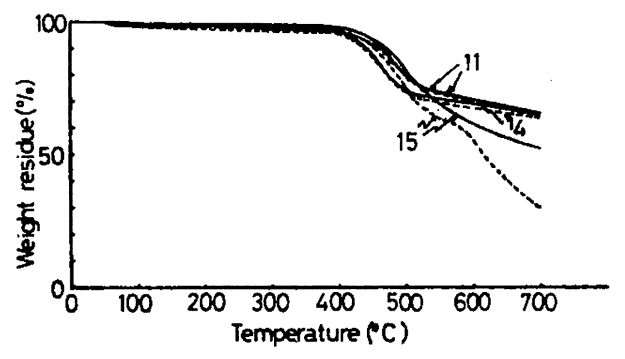

Fig. 3. TGA curves of polymers heated at a rate of $10^{\circ} \mathrm{C} / \mathrm{min}$ : - , in $\mathrm{N}_{2} ;-$, in air.

してDMF，DMA，DMSO などを用い，モル比 $1: 1$, 反応時䞒 $15 \sim 120(\mathrm{~h})$, 反庆温度 $3 \sim 80\left({ }^{\circ} \mathrm{C}\right)$ の年件下で ポリアミドーアミック酸を合成した. しかし，得られた ポリマーの DMA 中 $0.5 \mathrm{~g} / \mathrm{d} l, 30^{\circ} \mathrm{C}$ で測定した遣元粘 度は 0.06〜0.14で, 高分子县のポリマーは得られなか った.

そこで，鉿木らの方法") K徒って，高温無溶媒重樎合 を試みた。 まず，BPBDA とDDS の反応を例にして， $250^{\circ} \mathrm{C} お よ ひ ゙ ~ 300^{\circ} \mathrm{C} て ゙ 5 \sim 30$ (分) 反応を行い，最䔔条 件を検討した.

Fig. 1 に，反応温度と反応時間の影篦について検討し た結果を示した. すなわち, $300^{\circ} \mathrm{C}$ で反応恓めて速 やかに進行し，粘度は短時間でほぼ一定值となり，30分 では定量的な収率でポリマーが得られた。

次に，この結果を考にして，MPBDA，BPBDA お。 よび DCDA と考香族ジフミンから，20 mmHg の減圧 
含リンビスアミド無水物と芳香族ジフミンからのポリフミドーイミドの合成

Table 3. Thermal behavior data of polyamide-imides.

\begin{tabular}{|c|c|c|c|c|}
\hline \multirow{2}{*}{ Polymer No. } & \multicolumn{2}{|c|}{$\begin{array}{l}\text { Decomposition temperature }{ }^{2)} \\
\qquad\left({ }^{\circ} \mathrm{C}\right)\end{array}$} & \multirow{2}{*}{$\begin{array}{l}W_{s}^{\mathrm{b})} \\
(\%)\end{array}$} & \multirow{2}{*}{$\begin{array}{c}\left.\Delta E^{\mathrm{c}}\right) \\
(\mathrm{kcal} / \mathrm{mol})\end{array}$} \\
\hline & in air & in $\mathrm{N}_{2}$ & & \\
\hline 1 & 438 & 430 & 67 & 55 \\
\hline 2 & 443 & 438 & 71 & 48 \\
\hline 3 & 435 & 438 & 69 & 45 \\
\hline 4 & 448 & 445 & 75 & 56 \\
\hline 5 & 425 & 435 & 74 & 55 \\
\hline 6 & 435 & 430 & 65 & 40 \\
\hline 7 & 435 & 442 & 76 & 51 \\
\hline 8 & 438 & 440 & 75 & 50 \\
\hline 9 & 495 & 478 & 76 & 58 \\
\hline 10 & 460 & 452 & 66 & 52 \\
\hline 11 & 485 & 484 & 78 & 62 \\
\hline 12 & 492 & 495 & 74 & 55 \\
\hline 13 & 408 & 415 & 58 & 35 \\
\hline 14 & 503 & 505 & 59 & 52 \\
\hline 15 & 489 & 464 & 58 & 39 \\
\hline 16 & 505 & 508 & 53 & 55 \\
\hline
\end{tabular}

a) A $10 \%$ weight-loss temperature observed by TGA at a heating rate of $10^{\circ} \mathrm{C} / \mathrm{min}$. b) Amount of thermal decomposition residue in $\mathrm{N}_{2}$ at $700^{\circ} \mathrm{C}$. .) Apparent activation energy for thermal decomposition in $\mathbf{N}_{\mathbf{2}}$.

下で 30 分間, 温度 $300^{\circ} \mathrm{C}$, モル比 $1: 1$ の条件下で各

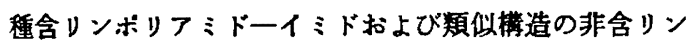
ポリフミドーイミドを合成した。

Table 1 に，その合成結果を示した。表から明らかな ように, ボリマーは 81 98\% の収率で得られ，迤元粘

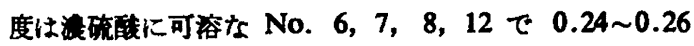
であったしかし，他のボリマーは流硫不容なため 測定できなかった. Table 2 にはポリマーの元来分析值 を示した.ボリマーの元素分析值はいずれの㙁合む，実 测値がポリマーの繰返し単位当たり数分子の水を吸着し たとして計算した值とほほ一致した，本報では後述する よ5に，TGA の重量減少から吸着水を確認したが，こ の重量滅少はポりマー鎖中のポリフミック酸が TGAの 高温城 $\left(100^{\circ} \mathrm{C}\right.$ 以上) で加熱脱水閉環してイミド環を形 成したために生じたとも考えられ，ボリフミドーイミド 中にボリフミック酸が一部残っている可能性がある.し かし，IR スペクトルからはボリフミック酸の存在は確 認できなかった. 又, リン含量の比教的多いNo. 7 お よび8のポリマーでは炭素の元素分析值が計算值よりも 幾分低い值を示したが，これは，一般に有樅りン化合物 の炭水策分析では残分中の炭素残留量が多くなる傾向が あるためと考えられるす。

3.3 含リンボリアミトーイミトの性㚇

生成ポリマーは黄色, 茶色, 褐色あるい黒色の粉末
で，いずれも DMF，DMA お゙よび DMSO などの有 機溶媒に不溶であるが, No. 6, 7, 8, 12 のポリマーは 瀑硫酸に可溶であった。これは反応させるジフミンが海 硫酸と親和性の強いS あるいはPなどのへテロ原子をも つためと思われる.

ボリマー (Polymer No. 1) およびモデル化合物の IR スペクトルを Fig. 2 に示した. ボリマーとモデル化合 物のIR スペクトルは類似の吸収スベクトルを示してお。 り, いずれの场合も 1250 および $1850 \mathrm{~cm}^{-1}$ の酸無水 物の吸収が消光， 1780 および $1720 \mathrm{~cm}^{-1}$ に新たにイ : ドカルボニルの吸収がみられ，1650および $1540 \mathrm{~cm}^{-1}$ にアミド基の吸収, $1430 \mathrm{~cm}^{-1} \mathrm{KP}-\mathrm{Ph}, 1170 \mathrm{~cm}^{-1} \mathrm{~K}$ $\mathbf{P}=0,1350 \mathrm{~cm}^{-1}$ Kイ ミ ド環の $\mathbf{C}-\mathbf{N}$ 伸縮振動の受収 がみられた. 以上のことから,ボリフミドーイミドの生 成を確認した。

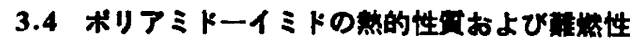

高温無溶媒重樎合によって得られたボリマーの空気中 および窒菜気流中における熱重量分析 (TGA) を行っ た. Fig. 3 には代表例として No. 4, 11, 15 のボリマ 一の TGA 曲線を, 又, Table 3 にはポリマーの就分 析の結果をまとめて示した。けずれの場合も $100^{\circ} \mathrm{C}$ 前後 に吸着水によると思われる $0.5 \sim 2.5 \%$ 程度の減量を示 して拈りこれは Table 2 の元菜分析の結果とほほ一 致していることが分かる：前述のように，この減量はボ 


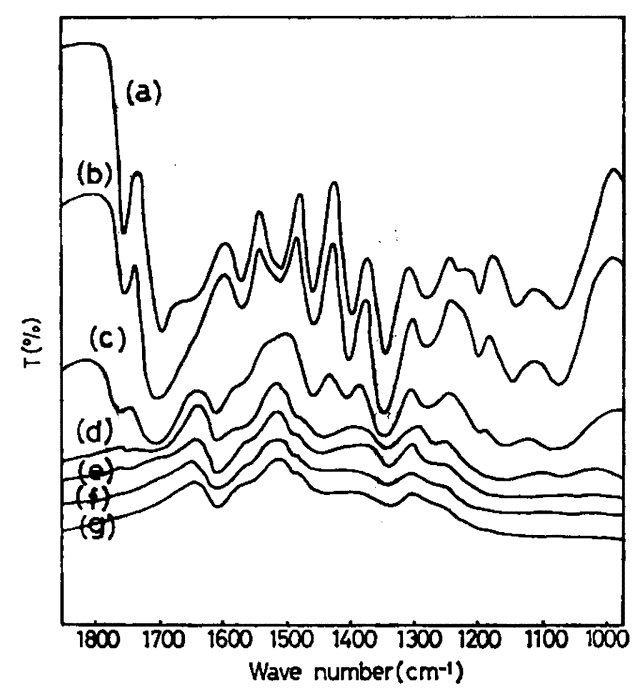

Fig. 4. IR spectra of the residual polymers after thermal decomposition (polymer No. 4) : (a), room temp.; (b), $350^{\circ} \mathrm{C}$; (c), $400^{\circ} \mathrm{C}$; (d), $450^{\circ} \mathrm{C}$; (e), $500^{\circ} \mathrm{C}$; (f), $600^{\circ} \mathrm{C} ;(\mathrm{g}), 700^{\circ} \mathrm{C}$.

リアミック酸の加熱脱水閉環によることも考えられる が，明らかではない，含リンボリアミドーイミドでは空 気中および空素気流中いずれの博合す急雄な重旦損失が みられず, $400^{\circ} \mathrm{C}$ 付近から $700^{\circ} \mathrm{C}$ まで徐ムに重是減少 しており， $700^{\circ} \mathrm{C}$ での重量残存量 $\left(W_{x}\right)$ は $65 \sim 78 \%$ と， かなり熱安定性が传れている.一方, 非含リンボリアミ ドーイミドでは $10 \%$ 重量損失温度は含リンボリアミ ドーイミドに比へると高い傾向がみられるが, $500^{\circ} \mathrm{C}$ 以

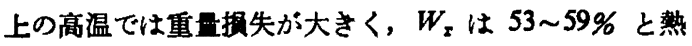
安定性が幾分含リンボリアミドーイミドに比べると劣る ことが分かる.これは，ポリマー銧中の $\mathbf{R}-\mathbf{P}=\mathbf{0}$ と $\mathrm{C}=\mathrm{O}$ との熱安定性の相違に上るるのと思われる. た，含リンボリフミドーイミド間では，MPBDA から 得られたポリマーの方が, BPBDA から得られたボリマ 一よりむ高い分解温度を示している.これは， $\mathbf{P}$ と結合 しているアルキル墓の立体効果のためと考えられる.

次に Freeman ${ }^{10)}$ の方法に従って, 分解率 5 20\%の 範囲で空素気流中における分解の見卦けの活性化エネル ギー $(\Delta E)$ を求めた. その結果, 含リンボリアミドーイ ミドでは $40 \sim 62 \mathrm{kcal} / \mathrm{mol}$, 非含リンポリアミドーイミ ドでは 32〜55 kcal/mol であった.

ボリマーの難然性と熱分解の夙係については，既に指

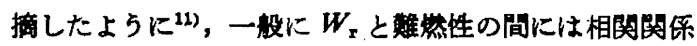
があり，Wx が多いるのにど奞然珄は高いといわれる ${ }^{12)}$. 含リンポリマーについても同様に考えられるため, 本研 究においても上述の熟分析の結果より, 含りンポリアミ
ドーイミドは難然性の点でかなり传れているものと考え られる. 又、含リンボリアミドーイミドの耐炎珄を定性 的に阔へたところ, いずれのポりマーも㷋から取り出す とただちに消火する程度の自己消炎性を示した。

Fig. 4 には, Polymer No. 4 のポリマーの各温度に お汁る整分解残留物の IR スベクトルを示した。これに よると、アミド基およびイミド基の吸収は，温度の上开

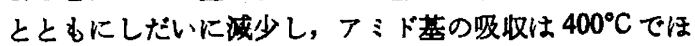
とんど消失し，新たに $1600 \mathrm{~cm}^{-1}$ 付近に吸収が現れてい る.これは $\mathrm{C}=\mathrm{N}$ の吸収と考えられ，700 Cにおいてる

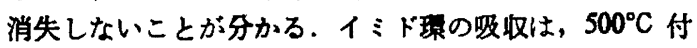
近までは若干みられるが, $600^{\circ} \mathrm{C} て ゙ は$ 消失している. 又, $\mathbf{P}-\mathrm{Ph}$ および $\mathbf{P}=\mathbf{O}$ の吸収は， $450^{\circ} \mathrm{C}$ までに消失 しており， $450^{\circ} \mathrm{C}$ から $\mathbf{P}=\mathbf{N}$ に基つくくのと思われる 吸収が $1330 \mathrm{~cm}^{-1}$ 付近に新たに現れている. $500^{\circ} \mathrm{C}$ 以上 の分解物の IR ペクトルには，ほとんど変化がみられ なかった.

蝴熱分析の测定に多大の御便宜と御指道をいた

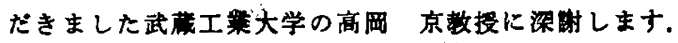

又，試料の提供を受けたイハラケミカル(株)に信意を表 します。なお，元来分析を担当された当研究室の大烟大 二郎氏に愔意を表します。

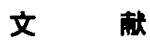

1) S. Hashimoto, I. Furukawa, and T. Kondo, J. Polym. Sci. Polym. Chem. Ed., 12, 2357 (1974).

2) O. Ya. Fedotova, V.I. Gorokhov, O.I. Paresishvili, G.S. Karetnikov, and G.S. Kolensnikov, Vysokomol. Soyedin., Ser, A, 14, 1256 (1972).

3) T. Ya. Medved', T. M. Frunze, Khu Chinmei, V. V. Kurashev, V. V. Korshak, and M. I. Kabachnik, Vysokomol. Soyedin., 5, 1309 (1963).

4) E. Dyer and R. A. Dunbar, J. Polym. Sci. Part, A-1, 8, 629 (1970).

5) L. H. Klemm, R. Mann, and C.D. Lind, J. Org. Chem., 23, 351 (1958).

6) E. C. Winslow and A. Laferriere, J. Polym. Sci., 60, 65 (1962).

7) 結城度夫, 木之下光男, 日本化学会誌, 1977, 549 .

8）鈴木刚彦，山绮㾜男，日本化学会誌，1973， 1029.

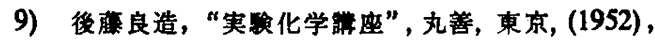
p. 199.

10) D. A. Anderson and E.S. Freeman, J. Polym. Sci., 54, 253 (1961).

11) 佐藤守之, 饭舯忠利, 内田高雄, 横山正明, 高 
分子綸文集, 35, 501 (1978).

12) D. V. van Krevelen, Polymer, 16, 615 (1975).

Preparation of Polyamide-imides from Phosphorus-Containing Bisamide-Anhydrides and Aromatic Diamines*

Masaru SeItA*1, Moriyuki SATo*1, and Masaaki YokoYAMA*1

*Studies of Phosphorus-Containing Polymers. XIV.

*1Department of Industrial Chemistry, Kogakuin University (24-2, Nishi-shinjuku 1-chome, Shinjuku-ku, Tokyo, 160 Japan)

Phosphorus-containing polyamide-imides were synthesized by the bulk polycondensation of 4,4 [3, 3'-(alkylphosphoryldiphenylene)-bis (iminocarbonyl)]diphthalic anhydride (APBPA) with aromatic diamines at high temperatures, and the reaction conditions were investigated. The polymers were insoluble in organic solvents such as DMF, DMA and DMSO. When diamines containing hetero atom ( $\mathrm{S}$ or $\mathrm{P}$ ) were used, the polymers were soluble in conc. $\mathrm{H}_{2} \mathrm{SO}_{4}$. Reduced viscosities of polymers measured in conc. $\mathrm{H}_{2} \mathrm{SO}_{4}$ solution at $30^{\circ} \mathrm{C}$ were $0.24 \sim 0.26 \mathrm{~g}^{-1} \mathrm{dl}$. Thermal analyses showed that the polymers degraded at $400 \sim 500^{\circ} \mathrm{C}$ in air or in nitrogen and that apparent activation energies for thermal decomposition under nitrogen atmosphere were $40 \sim 62 \mathrm{kcal} / \mathrm{mol}$. The polymers were selfextinguished immediately after the flame was removed.

KEY WORDS Phosphorus-Containing Polyamide-imide / 4, 4' $\left[3,3^{\prime}\right.$-(Alkylphosphoryldiphenylene)-bis (iminocarbonyl)]Diphthalic Anhydride / Bulk Polycondensation / Thermal Analysis / Apparent Activation Energy / Self-Extinguish /

(Received April 18, 1978: Accepted June 17, 1978)

[Kobunshi Ronbunshu, 35(11), 713-719 (1978)] 